\title{
Cytomegalovirus DNA
}

National Cancer Institute

\section{Source}

National Cancer Institute. Cytomegalovirus DNA. NCI Thesaurus. Code C148379.

The viral DNA that originates from cytomegalovirus. 